This item was submitted to Loughborough's Research Repository by the author.

Items in Figshare are protected by copyright, with all rights reserved, unless otherwise indicated.

\title{
A worldwide review of support mechanisms for car clubs
}

PLEASE CITE THE PUBLISHED VERSION

PUBLISHER

(C) Elsevier

LICENCE

CC BY-NC-ND 4.0

\section{REPOSITORY RECORD}

Enoch, Marcus P., and Jo Taylor. 2019. "A Worldwide Review of Support Mechanisms for Car Clubs". figshare. https://hdl.handle.net/2134/3332. 
This item was submitted to Loughborough's Institutional Repository by the author and is made available under the following Creative Commons Licence conditions.

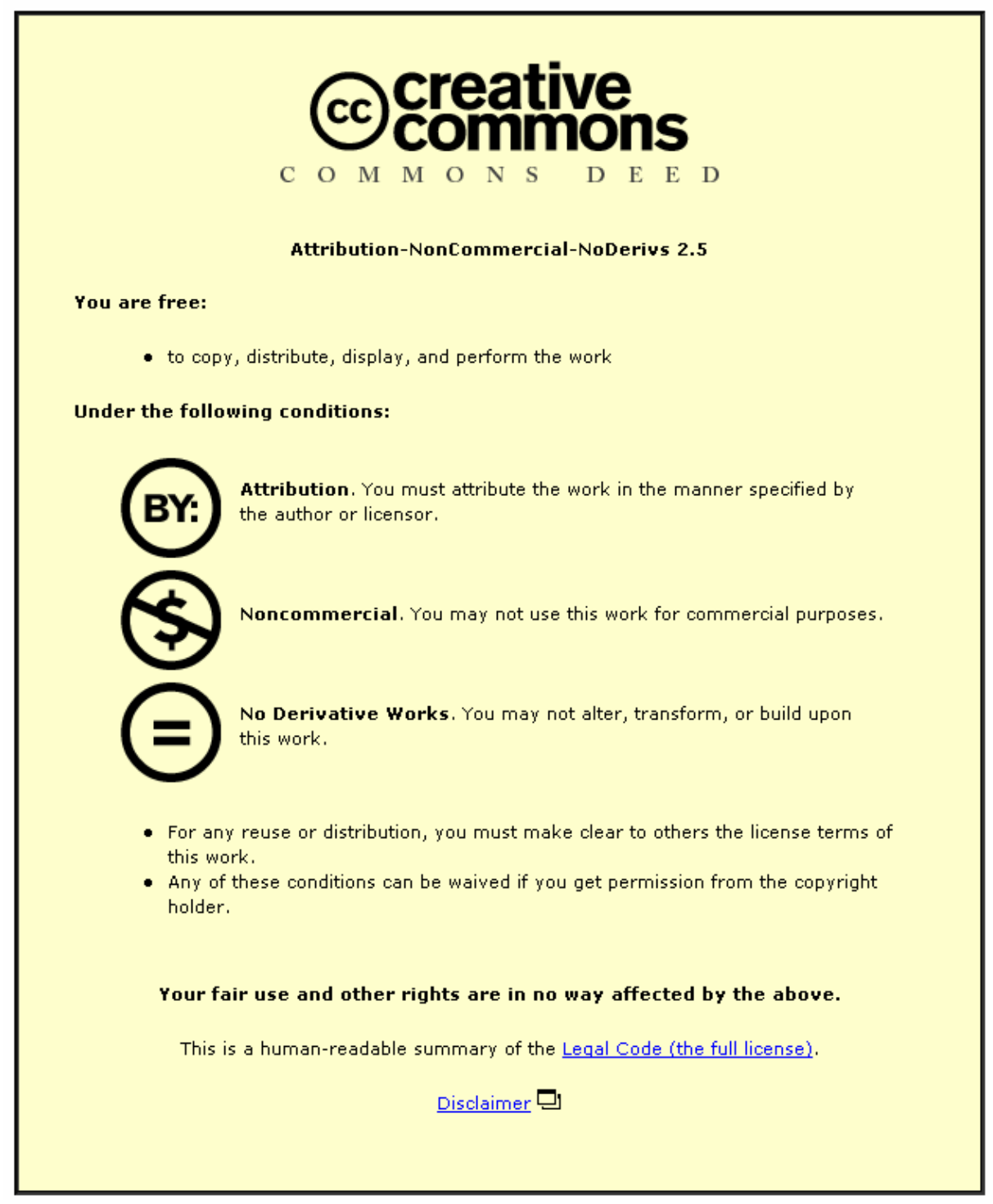

For the full text of this licence, please go to: http://creativecommons.org/licenses/by-nc-nd/2.5/ 


\title{
A worldwide review of support mechanisms for car clubs
}

\author{
Dr Marcus P Enoch*, \\ Transport Studies Group \\ Department of Civil and Building Engineering \\ Loughborough University \\ Leicestershire LE11 3TU \\ Jo Taylor \\ BioRegional Development Group \\ BedZED Centre, 24 Helios Road, Wallington, \\ Surrey SM6 7BZ
}

\begin{abstract}
Car clubs have operated on a large scale only since 1987, when the first scheme began in Switzerland, although prior to that there were several smaller scale projects. Schemes then spread to Germany, Austria and the Netherlands. More recently, car clubs have been set up in the UK, Denmark, Italy, and Sweden, and in Canada and the USA. These clubs have developed (and are still developing) in a number of ways. Some schemes are community-level schemes with only one or two vehicles, while others are national organisations with many thousands of members. And some schemes are run by volunteers and are non-profit making, while others are commercial ventures run by international companies.
\end{abstract}

Despite such diverse beginnings, it is clear that the vast majority of schemes face similar problems in becoming established. One major barrier has been the lack of involvement or support from local and national Government. Given the potential benefits of car clubs to deliver environmental and social improvements to communities, this is somewhat surprising.

As experience of car clubs spreads, this situation has begun to change and there are signs that Government attitudes across the world are becoming more enthusiastic to the idea of encouraging car clubs. This paper draws on the results of a state-of-the-art review, based on several face to face and telephone interviews, email communications, internet sites and existing literature to identify cases where such a change in attitude has occurred, how various levels of Government have translated this into action, and what lessons could be learnt from each example.

\footnotetext{
* Corresponding author: Tel: +44 (0)1509 223408; Fax: +44 (0)1509 223981; Email: m.p.enoch@lboro.ac.uk.
} 


\section{Introduction}

Ball et al (2001) defines a 'car club' as being: a 'pay-as-you-drive' club, that offers members access to a vehicle without ownership. Also known as 'city car clubs' or 'car sharing schemes', they have operated on a large scale only since 1987, when the first scheme began in Switzerland, although prior to that there were several smaller scale projects (Markusson, 2001). Schemes then spread to Germany, Austria and the Netherlands. More recently, car clubs have been set up in the UK, Denmark, Italy, and Sweden, and in Canada and the USA (see Shaheen et al, 1998 for a comprehensive background). Indeed, as of early 2005 Transit Cooperative Research Program (2005) reports that there are now more than 100 carsharing services with more than 120,000 members across Europe, and that Mobility CarSharing Switzerland, the largest of the European services, currently provides 1,800 cars at 900 locations for about 55,000 customers. In North America, Innovative Mobility Research (2005) states that as of December 2004, fifteen U.S. car clubs claimed 61,652 members sharing 939 vehicles, while in Canada over 10,759 members shared 528 vehicles among 11 car clubs.

Thus far, as may be expected for a relatively niche transport mode, any 'official' literature is rather scarce. One of the earliest references to car clubs was by Vuchic (1981). Interestingly, while he acknowledged that 'cars available to subscribers' offered a number of benefits compared with private cars, 'physical and operational problems... [together with issues to do with] maintenance, supervision of use and legal responsibilities' meant that 'the concept therefore does not appear to have much potential for use in cities'. Since then, much of the research has largely followed these two elements exactly what are these 'benefits' i.e. how car clubs perform as a transport mode - and how can these barriers facing car clubs be overcome.

\section{The benefits of car clubs}

From a policy perspective, car clubs are often credited with reducing car dependency, congestion, noise and air pollution, and the land needed for parking spaces, as well as increasing public transport use. In addition, car clubs offer access to cars for people too poor to buy one, so helping to reduce social exclusion (Ball et al, 2001). Similarly, Bergmaier et al (2004) notes that governments see economic, health, planning, transport and environmental benefits from car clubs.

Specific evidence on which to base these claims is apparently growing. Steininger et al (1996) draws on a survey of voluntary new car club members in two residential areas in Austria to report a substantial reduction of aggregate private vehicle mileage, predominantly through a reduction in trip lengths, along with a reduction in emissions and car ownership levels. Cervero and Tsai (2004) reports that experience in San Francisco suggested that when people join a car club they are far more likely to avoid buying a car (or additional car if they are already a car owner), while the average member drives 47\% fewer vehicle kilometres after joining. And, Huwer (2004) reports that car clubs are suitable as a supplement to public transport, based on an investigation of mobility behaviour and customer satisfaction in two German cities. 
However, Shaheen et al. (2004) urges caution in comparing results due to differences in data gathering methods among US car club schemes and more fundamentally in a report for the UK Government, Bonsall (2002) sees car clubs as only ever being a suitable mode in a few specific circumstances indicating that any impacts on the transport system and society generally would probably be relatively marginal. Finally, Shaheen et al (1998) notes that car clubs are more likely to thrive when environmental consciousness is high, driving disincentives such as high parking costs and traffic congestion are pervasive, car ownership costs are rather high, and alternative modes of transportation are easily accessible. The paper concludes, that 'an even more important lesson, though not well highlighted, is the need for partnerships and mobility management to offer enhanced products and services'. In other words, car clubs need to work with and be supported by other organisations with similar or at least complementary objectives - i.e. public transport operators and local authorities.

\section{Factors necessary for growth}

Car clubs have developed (and are still developing) in a number of ways. Some schemes are community-level schemes with only one or two vehicles, while others are national organisations with many thousands of members. And some schemes are run by volunteers and are non-profit making, while others are commercial ventures run by international companies (see Cousins (1999) and Barth and Shaheen (2002) for useful classifications of car club types). Despite such diverse beginnings, as with any new technology or policy it is clear that the vast majority of schemes face similar problems in becoming established.

Bonsall (2002) reports that good public transport, easy access to local services and a high population density were important elements found in 'successful' car clubs. Shaheen et al (1998) meanwhile finds that car clubs 'are more likely to be economically successful when they provide a dense network and variety of vehicles, serve a diverse mix of users, create joint marketing partnerships, design a flexible yet simple rate system, and provide for easy emergency access to taxis and long term car rentals'.

Meaton and Low (2003) looks at how rural car clubs in the UK had been set up and operated, and concludes that 'by creating awareness and gathering knowledge, the local champion appears to be a more significant factor in car club development than the geographical and socio-economic factors more commonly considered vital to the emergence and subsequent development of car clubs'. Drawing on the same rural UK study, The Countryside Commission (2004) reports that 'local factors rather than the typology of the local area were the reasons some clubs did not progress'. For instance, it points out that in one case a proposed car club area already had good public transport with low fares and a number of taxi firms, while in another there were high levels of affluence and private car ownership.

And, in a survey of Austrian car club members, Prettenthalter and Steininger (1999) reports that car club members tend to be highly educated, younger middle-aged, environmentally aware and never having owned an expensive car. It also estimates that the potential car club market to be around $9 \%$ of the population. 


\section{Identifying support mechanisms for car clubs}

Car clubs can therefore, provide transport and wider benefits to society, but if left to their own devices they are likely to only be economically viable in rather specific locations where the right cultural, geodemographic, economic, political and transport elements are in place. And, as cited earlier in Bonsall (2002), these conditions are not typically that widespread. Thus, there is an argument for public authorities to intervene and try and artificially generate more benign conditions to nurture car clubs, particularly in their vulnerable early stages (see Hoogma et al (2002) for an example of how this 'Strategic Niche Management' approach was applied in a case study of the development of Swiss car club organisations). Shaheen et al (2003) agrees, concluding that "the ability of this emerging sector to actualise its total environmental, economic and social goal may be limited without the collective support of private industry (e.g. automakers, insurance providers, technology producers); public agents (e.g. public transport and government agencies); and shared use vehicle programmes”. Department for Transport (Great Britain) (2004) also concurs, noting that 'effective delivery needs actions across a range of organisations, including national and local government, businesses and organisations, and car sharing service providers’.

However, while lip service is paid to the idea that support measures are a useful thing for policy makers studying car clubs to consider, rather less usable information is available on the role of supporting agencies and actors - a surprising omission given the range of public benefits generated by car clubs outlined earlier. Instead, research has focused on the ideal conditions required for establishing a car club, and also into the day-to-day minutiae of the factors important within a car sharing organisation.

One way of illustrating this, is by considering public policy as being driven far more by wider 'environmental' factors over which political actors have only limited control, than by parties, policies and ideas (Parsons, 1995). Hofferbert (1974) sees this ‘epiphenomenon perspective' as a 'funnel', whereby the policy agenda and the outcomes of political systems are functions of historical and geographic conditions, social and economic composition and mass political behaviour. Crucially though, these factors are then mediated or 'filtered' through governmental institutions and elite behaviour before they translate into a policy output, the level identified earlier as being where existing research into car clubs seems rather thin. It is this shortcoming that this paper aims to redress.

In a similar exercise looking at the role of public authorities supporting the development of travel plans, Enoch and Potter (2003) devises a framework of four support mechanism types that could be used, which were information, regulation, subsidies and the fiscal system. In this case, this frame has been modified slightly such that the first category (information) is widened to include policy support elements and so that the final two categories (subsidies and the fiscal system) are combined into one.

Therefore, the purpose of this paper is to identify cases where such a change in attitude has occurred, how various levels of Government have translated this into action, and what lessons could be learnt from each example. In brief, the paper draws on a comprehensive state-of-the-art review conducted for 
the EC-funded MOSES Project and on material gathered during a study tour of European and North American car club operators sponsored by the Winston Churchill Memorial Trust. Specifically, it draws on face to face interviews, telephone interviews and email communications with car club operators, local and national Government officials, car club support bodies and car club experts as well as internet sources and published and unpublished reports to set up vignettes of car club operations to identify how support measures have been used in practice and to make practical policy recommendations for national and local government.

\section{Policy support and informational measures}

One key barrier facing car clubs has been ignorance of what they are and what they are for. This has meant that at the strategic level there has often been an absence of political support for driving car clubs forward, while at the tactical level there have been problems in communicating the product to the (potential) user. This section will therefore look at cases where mechanisms have been developed to incorporate car clubs into national and local policy in a practical way, through providing information to policy makers; incorporating car club measures into policy; and integrating car club measures into the activities of other institutions. It will also look at examples of where car clubs have been effectively marketed at potential users.

\section{Information for public policy makers}

In Switzerland, the process of disseminating information to policy makers was aided by the Verkehrsclub der Schweiz (VCS) - the country’s most environmentally aware motorists organisation. VCS produced a manual for car sharing as early as 1989, developed publicity material and even helped start up car clubs in some locations. Most importantly, VCS eventually became the main channel of communication between car club operators and policy makers (Harms and Truffer, 1998).

A similar process occurred in Germany, where the Verkehrsclub Deutschland (VCD) conducted a similar role. Also in Germany, the Federal Government provided $€ 100,000$ over two years to fund academic research to explore the potential for car club membership. The research has predicted two million potential car club members in Germany (Holm, 2003).

In the Netherlands, the Government supported the establishment of the Stichtingvoor Gedeeld Autogebruik - The Foundation for Shared Car Use in 1995 with a number of mobility providers - to develop the concept that you “don’t need to own a car to drive a car” (Theunissen, 2001). The Foundation is a national independent organisation and stimulates and disseminates research on car sharing, for example on parking guidelines for local authorities. However, the use of a national 'autodate' identity (which suggests car clubs provide access to vehicles 24 hours a day seven days a week; neighbourhood vehicles; the ability to book for short periods; and simple payment and administration e.g. technology should be offered so that the member is not required to complete paper based trip records has not taken off as quickly as was hoped (Theunissen, 2003). 
In Italy, Decree 267 of 27 March 1998 of the Ministry of the Environment aimed to develop a national coordination and integration policy for car sharing through an organisation known as Iniziativa Car Sharing (City of Palermo, 2005; ICS, 2005). This body fulfils four major functions, namely:

- $\quad$ Fixed standards - guarantees interoperability between cities, sets minimum quality levels, and provides a corporate image and common user services;

- Co-financing - ICS provides up to $50 \%$ of scheme set up costs with a budget so far of $€ 5.1 \mathrm{~m}$ (Loose et al, 2004), although it should be noted that these grants are given out as goods and services, not as cash.

- Operational fields and services - provides clubs with technical, marketing, communication and legal support.

- $\quad$ Promotion and coordination - aims to spread car sharing experience in a coordinated way.

As of April 2005, ICS (2005) reports that car clubs in Italy had more than 3700 members, 155 vehicles and 89 reserved parking spaces, which translated to more than 1,500 customers travelling more than 80,000 kilometres each month.

Overall, the formation of nation-wide organisations to 'educate' policy makers and the wider public as to the role and benefits of car clubs was a key reason that such schemes prospered in Switzerland and Germany. Conversely, probably the major barrier faced by car clubs in Canada and the USA, is the ignorance of local authorities of the whole car club concept.

\section{From information into public policy}

Meanwhile the key way of mainstreaming an idea in the political arena is to devise a policy on it. Thus, policy statements describing how car sharing might help to achieve environmental, social or economic objectives offer an explicit form of support.

At a national level, the Dutch Government charged the "Stichtingvoor Gedeeld Auotgebruik" with developing a national car sharing strategy (Harms and Truffer, 1998; Theunissen, 2001). This aimed to conduct five tasks:

- Information and communication (under a common logo and name - Autodate);

- $\quad$ Facilitation of private car sharing (contracts, assurances etc.);

- $\quad$ Linking private and business car sharing (setting up car clubs for firms);

- Development planning (e.g. establishing car sharing in new residential areas)

- $\quad$ Quality protection (research and monitoring). 
At the city level, Toronto City Council adopted a report made to the Urban Environment and Development Committee to support car sharing (Stewart, 1999). This suggested that:

"building on its support for such initiatives as Auto Share and FAAN, the City of Toronto should continue to encourage and promote the implementation of car sharing programs through the consideration of such measures as:

- $\quad$ providing start-up loans through the Toronto Atmospheric Fund;

- $\quad$ supporting the publicity and promotional efforts of car sharing programs;

- $\quad$ facilitating the provision of parking facilities for car sharing, and

- $\quad$ incorporating car sharing as an element of the City's wider "Moving The Economy" initiative to develop Personal Mobility Systems as part of the strategy to move towards a sustainable transportation system."

King County Metro (Seattle’s major public transit agency), took a further step, and actively helped establish a car sharing programme as part of its 'regional mobility manager' remit. Metro works closely with the City of Seattle, which itself states that car clubs are a key element in its 1999 Transportation Strategic Plan. In addition, the City has pledged to encourage car sharing in new housing and commercial developments (Lindmark, 2001; Kadesh et al, 2000). And, two German cities - Hanover and Dresden - have integrated car clubs into their city-wide public transport plans. This has no immediate practical implications but such support takes the important political step of recognising car clubs as part of the public transport infrastructure (Röhrleef, 2003).

In summary, explicit political support for car clubs is crucial if they are to consistently attract the tactical support available from Government, local authorities and other bodies such as public transport operators or developers. If this is not present, it is likely that while 'one-off' concessions are sometimes granted, developing a scheme is generally a struggle. Where car clubs are explicitly recognised in policy documents, the chances are that a far more coherent approach to developing car sharing results.

\section{Integrating car clubs with other institutions}

Another useful function for supporting agencies is to facilitate links between car clubs and public transport operators so that new ticketing, information and marketing products can be developed.

In Hanover, Germany, public transport season ticket holders pay a reduced car club joining fee (€50 rather than the usual €129) and no membership fee, but pay a higher hourly rate than standard members in a bid to encourage season ticket holders to try the car club on a low risk basis (Röhrleef, 2003). Meanwhile in a parallel initiative, public transport operator Üstra sells season tickets to car club operator teilAuto at a bulk discount rate which then passes the offer to its members. In addition, both organisations have undertaken a number of marketing and information initiatives together, e.g. the 
Üstra logo was added to the teilAuto smart card, while Üstra provides a public transport map of the city which includes car club locations. Further collaboration occurs in that teilAuto vehicles are used by Üstra on a day to day basis for use as pool vehicles, and a number of car club stations are located at Üstra bus and tram depots. Before this collaboration began in 1999, teilAuto had 1,100 members, but this more than doubled to 2,500 members within two years and has remained stable at this level to date. There are 80,000 season ticket holders in the area. An Üstra survey of season ticket holders who are also car club members showed that $12 \%$ sold a private car as a result of the offer and a further third said that they would have purchased a car without the offer. This demonstrated to Üstra that the collaboration with teilAuto is retaining customers for public transport. Most recently, Üstra and teilAuto are working together to develop a comprehensive mobility package which delivers public transport, cycling, car club, taxi and delivery services on a single smart card.

In Seattle, the lead role of public transport operator King County Metro in the car club has meant the concept has been integrated with conventional transit operations from the beginning (Kadesh et al, 2000). To help a car club to grow quickly enough to allow effective integration with public transport, tender proposals were invited from potential car club operators in return for \$US200,000 (€230,000) per year, co-operation on marketing, office space and a secondment to assist in the start-up phase from King County Metro (Lindmark, 2003).From the outset, King County set specific goals for the car club programme:

- demonstrate viability of car club in a USA city

- demonstrate integration with public transport partners

- demonstrate that car clubs work outside high density residential neighbourhoods e.g. in downtown business districts

- use public money to draw private capital

As Flexcar has grown, King County’s role has evolved. Today, it facilitates links with large employers and encourages the inclusion of Flexcar in 'transport demand management commute plans (workplace travel plans). Also, rather than contributing \$US200,000 (€230,000) annual subsidy in cash, King County now provides the equivalent in incentives - e.g. by offering 'Flexpass' (public transport pass offered by employers) holders discounted car club membership or free usage time or matching dollar for dollar any money that a business puts into the Flexcar programme. The transit agency has also assisted with fundraising, including securing an Environmental Protection Agency grant that facilitated the addition of 20 hybrid vehicles to the Flexcar fleet by funding the price premium over a conventional vehicle. There is anecdotal evidence that Flexcar is generating new public transport users - but this has proved difficult to quantify. Market research shows that Flexcar members have sold cars and/or have postponed car purchases as a result of using the service. 
Similar public transport operator-led arrangements are being developed in Italy, Germany and Belgium. Indeed, public transport operators have become shareholders in the car clubs located in Turin, Dresden and Brussels (Loose et al, 2004). The Massachusetts Bay Transportation Authority (serving Greater Boston) allows zipcar to locate its vehicles at metro stations and participates in joint marketing initiatives (Rosenzweig, 2003). In Hull, Quebec the local public transport operator is to let members of a soon-to-be-launched car club pay discounted fares on its buses, by allowing the Communauto Car club register its members as 'employees'. This entitles them to a transit pass that gives a 15\% fare discount (Roberts, 2001).

Holders of the 'Bremer Karte +' public transport season ticket in Bremen, are able to access both public transport and the Cambio car club vehicles with a single smartcard. This arrangement is seen as being commercially beneficial to both BSAG (Bremer Strassenbahn AG ) and Cambio due to the complementary nature of both products (Traue, 2003). And a similar scheme exists in Stockholm (Badenhop, 2001). Bristol City Council has provided advice, publicity, and technical and financial support to the Bristol Environmentally Sustainable Transport (BEST) Car Club since the scheme's launch (Cox, 2001). And, local bus operator First Bristol offers 10\% off its pre-paid fares for BEST car club members (Carplus, 2001).

The attractiveness of the presence of a car share to potential property buyers has also led to developers initiating the link between car share operations and providers of public transport. Residents of the Vauban project in Freiburg who join the Freiburger Auto Gemeinschaft car sharing club are, on payment of the DM700 (€360) joining fee (half of which is refunded when they leave), offered a special mobility package. This allows membership of the car sharing organisation together with a oneyear free pass for all public transportation within Freiburg as well as a one-year 50\% reduction on every train ticket in form of the "Bahncard.” (Scheurer, 2001).

In Singapore too, the Co-op Car Club benefited from the support of the developers of two neighbouring condominiums who saw car sharing as a way of enhancing their apartments. Residents automatically become members of the car club and have access to a fleet of a variety of types of shared cars. These members do not pay membership fees during the first years, but pay for usage. The two developers are each paying approximately \$SG100,000 (€62,800) towards this operation during the first three years of the programme. As it expands, around one car for every 40 residents is to be provided. More generally in Singapore car sharing lots are also being located near public transit stations, so users can rent vehicles at the end of a transit trip thus effectively physically integrating the mode with conventional public transport (Meng, 2001).

Such initiatives demonstrate that backing for publicity and marketing of car clubs is one area that offers great potential. Many local authorities have strong links with public transport operators and are able to influence ticketing strategies to incorporate car clubs. This makes good sense as having access to a car club as an option if public transport is not suitable for a particular journey could provide a good reason not to buy or own a car. The link with local developers seeking planning permission is also a useful one for promoting car clubs (see next section for more examples). Indeed, national German car club 
association BCS suggests an extra public transport spend by car club members of $€ 25-€ 75$ per annum (Holm, 2003). On the other hand, the same report found that a number of car club operators have reduced car club membership benefits to public transport users as the cost proved too high. As a result, some car clubs have lost up to $25 \%$ of their membership. In some cases these losses have cancelled out more recent membership growth.

\section{Regulatory approaches}

There are two major ways that regulatory support has been provided to car clubs - through parking restrictions, and through the planning system.

\section{Help with parking}

At a tactical level, provision of 'usable' parking is perhaps the support most appreciated by car clubs. This can be done in several ways ranging from providing parking (along with 'protection' of those spaces) to car sharing, through providing the spaces alone, giving parking permits, and giving discounts for parking permits, to just giving priority to car sharing clubs for any spaces that become available. Local authorities can also encourage developers or private parking companies to provide parking spaces for car sharing organisations.

In the Low Countries, there are national guidelines allowing car club vehicles to access on-street sites, and special signs have been drawn up to indicate areas where car club cars may be parked. One national Dutch car club company Greenwheels has worked for more than four years closely together with municipalities and national government now has over 200 kerbside parking spots in 14 cities that are enforced by municipalities (Borghuis, 2001). A similar arrangement also exists in Belgium between the Wallonie Regional Government and the non-governmental organisation Taxistop (Loose et al, 2004).

Portland, Oregon is one city in the USA that has provided a number of parking spaces to the local car sharing operator. This was achieved using a process similar to that used to designate taxi stands, i.e. by regulating parking for classes of vehicles but not specific vehicles. The City also enforces parking spaces as they are 'protected' by 'reserved signs' (Brook, 2001; Martin, 2001).

Similarly, the City of Seattle has provided operator Flexcar with 30 on-street parking spaces, following a successful demonstration project which piloted eight on-street bays. These are allocated on a similar basis to the designation of spaces to taxi operators (del Valle, 2003). In addition, Seattle has provided financial and staffing resources - \$US60,000 (€69,000) over two years - to help secure parking for the car sharing club (Patton, 2001; Kadesh et al, 2000). Meanwhile King County, Seattle’s transport authority, is seeking to reduce parking standards to support public transport use. This may include a policy whereby a developer providing car club services would not be required to provide as many parking spaces (Lindmark, 2003). 
The City of Alexandria, just outside Washington DC, is piloting the provision of two on-street car club parking spaces near to Metro stations. If the car club service proves popular, the City plans to roll out on-street parking via car club members requesting the opportunity to 'sponsor' a car club bay outside their home. Here, zipcar would pay a nominal fee of \$US50 (€58) per month per space - roughly two thirds of the cost paid by individuals. This approach has made the granting of on-street parking more politically palatable and rewards supportive members with a zipcar on their doorstep (Chase, 2003).

German law prohibits the use of special reserved and signposted public space for parking other than for buses, taxis and disabled drivers and so there is no on-street parking for car club vehicles. However, this may change as one form of on-street car club parking - 'mobil.punkt', where on-street car club stations are integrated with bus or tram stops, cycle parking and a public transport information point is currently being piloted by the City of Bremen together with operator Cambio (Traue, 2003). This is important as the German car club association BCS suggests that the lack of access to on-street parking is a key factor in holding back membership growth (Holm, 2003).

Off street parking is more typically provided. The City of Cambridge, Massachusetts has allocated parking spaces to operator zipcar which are subsidised for the first two years. Where the City is unable to offer discounted parking spaces it is still able to help access desirable parking spaces (Slotnick, 2003) Meanwhile the neighbouring authority of the City of Boston has produced a guidance document 'Parking in Boston' that includes a page describing the needs of car clubs. Car club operators have found this particularly useful when approaching developers for support (Chase, 2003).

And, in Toronto, Ontario car club Autoshare is given a 30\% discount on monthly parking permits by the City Council. Further, many of these parking lots are located near to the Toronto subway system, which allows members to use the subway should no car club vehicle be available (Reynolds, 2001).

Provision of parking spaces is often the most important way that local authorities and developers can support car clubs. Ideally, spaces should be accessible to members, perceived to be safe, be as close as possible to where members live and/or work, and be visible to prospective members. Where necessary, spaces should also be 'protected' from being used by other motorists by traffic regulations and traffic wardens. Discounts on rent for car club parking spaces are also appreciated.

\section{Planning support}

A second way that regulations have been used to support car clubs, is through alterations to the planning code to allow developers to reduce the parking they are required to provide in return for help with any of the above.

One Dutch car free housing project that has included car sharing within it, is the 600-unit GWL-terrein project in the Westerpark district of Amsterdam. This is located about 3km from the city centre and was completed in 1998. The streets surrounding the development are controlled parking areas, and 
residents of the development are ineligible for permits. Around 10\% of households have joined the car sharing scheme (Scheurer, 2001).

Portland, Oregon is somewhat more progressive than many US cities and has been allowing residential housing developers as low a ‘floor area [to parking space] ratio' (FAR) as they want, and as their financing source will allow. However, as yet there is no designated FAR bonus written into the building code. To that end, one city councillor is sponsoring a sort of 'focus group' with local developers to scope out the issues as they see them (Brook, 2001; Martin, 2001).

The Green Party in Vienna sought to build a car free development for many years. But the project was stymied for a long time due to a legal requirement that one parking space was to be built for each apartment. Construction of a 250-apartment block - the Autofreie-Mutersiedlung housing development in Floridsdorf, some 9km from the city centre - began in 1997 when an exemption was obtained, and full occupancy was expected by 1999. Parking provision was reduced from 250 to 25 spaces which are exclusively for car club vehicles. Interestingly, this cut in parking provision saved the developer some ATS22m (€1.6m) - or 9\% of the total construction budget. Free membership of the car club is offered for the first year, and 57\% of households have taken up the offer. Facilities are nearby and public transport links are good. Over half of the residents cited the car free nature of the development as the reason for living there. Residents are obliged to abstain from owning a vehicle by an article in their lease. However, although Austrian law does not permit eviction if this clause is violated, as of October 2000 no enforcement had been required. Alternative instruments could include the withdrawal of housing subsidies or a forced apartment swap should the tenant refuse to give up their car (Ball et al. 2001; Crawford, 2000; Scheurer, 2001).

The technique of using planning guidelines to encourage car sharing schemes is not particularly advanced as yet. While relatively few local authorities have either changed or plan to change their planning rules to incorporate car clubs, many more are slowly beginning to allow developers to negotiate deals where setting up car clubs is an acceptable way of reducing the amount of parking required. There is also evidence to suggest that much of the pressure for setting up car share stations on developments is from the developer and not the local authority - with developers actually using the car club as a selling point.

\section{Fiscal mechanisms}

Financial support for car clubs has tended to be offered to help start up the club and to buy and run vehicles, plus financial and organisational help to market the scheme effectively. At a national or state level, tax breaks for car club users and/or operators have also been provided.

\section{Direct and indirect subsidy}

Public funding has been key in establishing the Edinburgh car club. Initially the City of Edinburgh Council paid £48,000 (€78,500) to help kick-start the scheme, while £150,000 $(€ 245,000)$ came from 
Central Government for technology and other set up costs, and £30,000 (€49,000) from the Scottish Executive to cover the cost of monitoring the project. Unfortunately, this first scheme closed when car rental firm Budget decided to drop out, having decided that the operation was not commercially viable. As of September 2001, car share operator Smart Moves took over the contract, with the council agreeing to pay $£ 40,000$ (€65,500) over two years to help with publicity and marketing of the relaunched scheme (Hobley, 2001; Saunders et al, 1999).

Start-up grants have been used elsewhere too. For example, Toronto City Council provided a \$CAN20,000 (€14,400) loan to help the club 'get off the ground' from the Toronto Atmospheric Fund, and facilitated the relationship between the car club and the Toronto Transit Commission (Reynolds, 2001). In Philadelphia, Pennsylvania the PhillyCarShare receives federal funding from a package designed to deliver improvements in air quality (Millard-Ball, 2003).

Indirect subsidies have also been offered to help stimulate car club services. The City of Edinburgh Council guaranteed that it would use the car club service (Saunders et al, 1999), while the municipal administration in Cologne, Germany sold off its car fleet and its employees have used StattAuto vehicles since 1997 (ECS, 1999). Meanwhile the Foundation for Shared Car Use provides local councils with car club 'experts’ to help them set up their own networks (Theunissen, 2001).

Financial support can also be offered through private developers. In a one-off deal with a local building contractor, car club Gemeinschaftsauto in Esslingen, Germany was provided with a fully paid for vehicle and free parking space, while the developer sold 'flats with car sharing' (Mezger, 2001). And in Deptford, in the London Borough of Lewisham, developer St James Homes and rental car company Avis are to launch a car club with 19 vehicles at 'One SE8'. The developer will pay a $£ 99$ (€160) annual membership fee for one member of each household to join the car club in the first year, and approached Avis to help overcome the tight parking standards set by the planning authority in the planning agreement (Bond, 2001).

\section{Tax breaks}

The State of Oregon uses tax breaks to encourage car sharing. Energy conservation bill (State Bill 521) gives tax credits to businesses that carry out certain energy-saving activities, including provisions allowing car clubs to increase availability of parking spaces to locate their cars. It became law on 25 June 2001 (Brook, 2001).

Financial support for car clubs is generally targeted to meet specific needs. Britton (2001) sums up this approach, noting that: "the kind of support that is needed for car sharing is quite different from the more traditional role between local government and the transportation system. Experience shows that what is needed is not great clots of taxpayer moneys to fund the whole thing, but rather an attentive and capable local administration that is ready to come in and provide a wide range of 'softer' support functions". 


\section{Support needs for car clubs}

From the vignettes described above, it is clear that there are several areas where car clubs have benefited from the support of Government, local councils, and other bodies. These were through:

1. Information

- Intellectual backing - i.e. through setting up organisations to disseminate information to various potential 'support agencies' to inform them of the car club concept and its benefits.

- Political support - in the form of policy initiatives.

- Links with public transport operators, so that new ticketing, information and marketing products can be developed.

2. Regulation

- Provision of ‘usable’ parking spaces.

- Alterations to the planning code to allow developers to reduce the parking they are required to provide in return for help with any of the other support measures.

3. Fiscal mechanisms

- Funds to help the club buy and run vehicles.

- Financial and organisational help to market schemes effectively.

- Tax breaks for car club users and/or operators.

All in all, one car club operator to have benefited from a whole package of measures, is the San Francisco-based City CarShare, a not-for-profit organisation which began operating in spring 2001.

In terms of support, San Francisco City CarShare is politically integrated into a whole range of organisations including the City Council, the Metropolitan Transit Commission, San Francisco Transit Authority (MTC) and Bay Area Rapid Transit (BART). It is also a key part of a number of social programmes such as 'Calworks', which are designed to improve the quality of life of socially disadvantaged groups (Bourdon, 2003).

Each of the partners also helps with marketing, monitoring and promoting the car club scheme.

With parking, the City provided free spaces for the first two years - a significant gift when spaces are rented at \$US200-\$US500 (€230-€575) per month and difficult to access - and now charges the car club at a favourable discount of around $40 \%$ below the market rate (Bourdon, 2003). 
On the planning front the City adopted a resolution in autumn 1999 to formalise the role that car clubs can play in development policy in the city. While the resolution has not been formally introduced into the planning codes, the City of San Francisco’s Planning Commission already actively uses car clubs as a development tool. For instance, where a planning application proposes a reduction on the normal parking standard of one space per unit, the Commission can require City CarShare services to be offered to compensate. Where developers seek additional parking spaces above the standard, the Commission may grant all or a percentage of the extra spaces and require - say two - spaces to be allocated to City CarShare in mitigation. The City is working towards formalising this approach into planning policy. As of spring 2004, the City had sought inclusion of car clubs in 40 new developments in return for reduced parking standards. City Car Share had concluded agreements on ten developments, two of which are now completed and occupied (Bourdon, 2003).

Financially, the City acts as the delivery mechanism and monitoring agent of a Federal Government grant of \$US750,000 (€863,000). Meanwhile \$US200,000 (€230,000) general funding has been provided by the San Francisco County Transit Authority over the past two years. And, around \$US2.5m (€2.9m) a year is to be received by the car club from the Metropolitan Transportation Commission, in its role as the Bay Area Toll Authority as a part of a package of projects to relieve congestion and expand public transport services in the vicinity of bridge corridors. Overall, the \$US1 (€1.15) increase in the toll for the Oakland Bay Bridge (which San Francisco voters approved in March 2004) will raise around $\$ U S 125 m(€ 145 m)$ a year.

Overall, looking at the growth of the scheme it is clear that the support from the range of informed partners (in particular the local authority) certainly does no harm to the development of a car club. Indeed, as of August 2001 the City CarShare had 25 cars for 625 members (White, 2001), while by Autumn 2003 the figures were 2,700 members using 80 vehicles across 40 locations throughout the Bay Area (Bourdon, 2003). The latest data (July 2005) saw more than 4,000 members, using 90 vehicles at 45 sites (DeBarre, 2005).

One interesting development though, is news that a second operator - the commercial company zipcar - is to launch a new club in the city in direct competition (DeBarre, 2005). Such a move raises interesting questions about the future of car clubs relating to support strategies in the future and presents a potential future research topic as to what the nature of relationships between car club operators, developers, public transport companies and local authorities should be.

\section{Conclusions}

In conclusion, the case studies illustrate a wide variety of ways that government bodies and private developers can help support 'successful' car clubs. However, so far this has often not been granted - in the main due to a lack of understanding about what a car club actually is. 
While the situation has improved in recent years, it is still the case that many local authorities do not know how to effectively deal with car clubs. This situation is compounded by a lack of car club policy guidance from national government. As a result, building a relationship with a local authority is dependent on the presence of a 'champion' officer who is prepared to work outside a policy support framework and a considerable investment of time from a car club operator. Valuable time is therefore spent 'reinventing the wheel' rather than focusing on other aspects of business development. This has meant that many schemes have struggled to survive, never mind develop.

National car club 'umbrella bodies' such as the Dutch Foundation, BCS in Germany, ICS in Italy and the UK's Carplus have helped to bridge this gap by developing car club accreditation schemes. Such mechanisms can help local authorities define, for instance, eligibility for access to on-street parking and other support benefits.

It is clear that the focus of national and international car club advocacy groups such as World Car Share Consortium and European Car Share must be on working with policy makers to achieve policy change. Car clubs need to be recognised as an important element in strategies designed to reduce reliance on the private car - at all levels. With these strategic elements in place, it should then be easier for car clubs to call upon further means of support (be they parking, planning, publicity, marketing, or financial) where needed.

Overall, the experiences detailed illustrate that support from informed partners can help accelerate the development of car club schemes, and make their survival more likely. Local support measures, particularly those that give car club users an advantage over other motorists, seem the key to success. But these need to be tailored to local situations while being consistently supported by a 'friend with clout'.

\section{References}

Badenhop K (2001) Personal communication, Bremen Initiative Managing Agency and the Bremen Partnership Award Office, Bremen, Germany, 4 October.

Ball C, Best W, Ray A, and Seasman A (2001) Achieving low car housing: the role of car clubs, A good practice guide for planners and developers, Produced for the Regional Assembly for Yorkshire and Humberside by a working group led by the Community Car Share Network, Leeds, UK, June.

Barth M and Shaheen S (2002) Shared use vehicle systems: Framework for classifying car sharing, station cars and combined approaches, Transportation Research Record, 1791, 105-112.

Bergmaier R, Mason C, McKenzie M, Campbell S and Hobson A (2004) Car sharing: An overview, Department of the Environment and Heritage, Australian Greenhouse Office, Australian Government, Canberra, Australia. 
Bond R (2001) Housing developer signs deal for doorstep car sharing club, Surveyor, 13 September, 7.

Bonsall P (2002) Car share and car clubs: Potential impacts, Department of Transport (Great Britain), Local Government and the Regions and The Motorists Forum, London, UK.

Borghuis J (2001) Personal communication, Greenwheels, Rotterdam, Netherlands, July.

Bourdon, A (2003) Interview, San Francisco Director, City CarShare, San Francisco, CA, 15 October.

Britton E (2001) CarSharing 2001: Some Questions and a Few Reflections on the Future of

Carsharing, The World CarShare Consortium, EcoPlan and The Commons, Paris. Visit

http://www.worldcarshare.com. Accessed 13 July 2005.

Brook D (2001) Personal communication, CarSharing Portland, Portland, OR, July.

Carplus (2001) UK round up, Carplus the car club network update, Winter.

Cervero R and Tsai Y (2004) San Francisco City CarShare: Second year travel demand and car ownership impacts, Transportation Research Record, 1887, 117-127.

Chase, M (2003) Interview, Director of Planning and Market Development, zipcar, Boston, MA, 10 October.

City of Palermo (2005) Car sharing in Italy: ICS project, Keys to Car Sharing: Moving the city of tomorrow, European Commission DG Research 5th Framework Programme City of Tomorrowsponsored MOSES (Mobility Services for Urban Sustainability) Project, 27-28 January, Brussels, Belgium.

The Countryside Agency (2004) Rural car clubs, The Countryside Agency, Cheltenham, UK, October.

Cousins S (1999) Carsharing? An alternative vision and a bit of history, World Transport Policy and Practice, 5(3), 47-56.

Cox A (2001) BEST experience from Bristol, Town and Country Planning, May, 70, (5), 145.

Crawford J H (2000) Car Free Cities, International Books, Utrecht, Netherlands.

DeBerre I (2005) City CarShare to get first taste of competition: Using VC funding, for-profit Zipcar to start service in Bay Area, San Francisco Chronicle, San Francisco, CA, 15 July.

del Valle, W (2003) Interview, General Manager, Flexcar, Seattle, WA, 5 November.

Department for Transport (Great Britain) (2004) Making car sharing and car clubs work, Review of formal car sharing and car club schemes in closed communities, including the workplace, Final Report, Project UG 513, Department for Transport, HM Government, London, UK, December. 
Enoch M P and Potter S (2003) What incentives to the commercial sector can help employees to change travel behaviour? Transport Policy, 10(1), 51-58.

European CarSharing (1999) CarSharing in Europe, CD-ROM on CarSharing - the mobile alternative in Europe, European CarSharing. Visit http://www.carsharing.org/. Last accessed 3 August 2005.

Harms S and Truffer B (1998) The emergence of a nation-wide Carsharing Co-operative in Switzerland: A case study for the project Strategic Niche Management as a tool for transition to a Sustainable Transportation System, EAWAG, Switzerland, March.

Hobley M (2001) Edinburgh finalises details for 'more modest' car sharing club, Surveyor, 6 September, 7 .

Hofferbert R (1974) The study of public policy, Bobbs Merrill, Indianapolis, IN.

Holm B (2003) Interview, BCS, Cologne, Germany, 24 September.

Hoogma R, Kemp R, Schot J and Truffler B (2002) Experimenting for sustainable transport: The approach of Strategic Niche Management, Spon Press, London, UK.

Huwer U (2004) Public transport and car sharing - benefits and effects of combined services, Transport Policy, 11(2), 77-87.

Iniziativa Car Sharing (2005) Car sharing in Italy, Iniziativa Car Sharing. Visit

http://www.icscarsharing.it. Last accessed 18 June 2005.

Innovative Mobility Research (2005) Carsharing and Station Cars. Visit

http://www.innovativemobility.org. Last accessed 24 June 2005.

Kadesh E, Lindmark R, Anderson C and Roach W T (2000) Public Agency Support for Car Sharing:

The Seattle Experience, Transportation Research Board, 00-0953, Washington DC, January.

Lindmark R (2001) Personal communication, Outreach Co-ordinator, King County Metro, Seattle, WA, July.

Lindmark, R (2003) Interview, Outreach Co-ordinator, Flexcar Car Sharing Service Development Section, King County Metro, Seattle, WA, 6 November.

Loose W, Mohr M, Nobis C, Holm B and Bake D (2004) Bestandsaufnahme und Möglichkeiten der Weiterentwicklung von Car-Sharing. Berichte der Bundesanstalt für Strassenwesen, Reihe Verkehrstechnik, Heft 114, Bergisch-Gladbach, Germany.

Markusson P (2001) Personal communication, Advice - Carsharing - Environment, Gothenburg, Sweden, 19 September. 
Martin R (2001) Telephone interview, CarSharing Portland, Portland, OR, July.

Meaton J and Low C (2003) Car Club development: The role of local champions, World Transport Policy and Practice, 9(3), 32-40.

Meng L (2001) Personal communication, NTUC Car Co-operative, Singapore, July.

Mezger C (2001) Personal communication, VCD-Gemeinschaftsauto, Esslingen, Germany, August.

Millard-Ball, A (2003) Interview, Senior Associate, Nelson-Nygaard, San Francisco, CA, 14 October.

Parsons W (1995) Public policy, Edward Elgar, Cheltenham, UK.

Patton A (2001) Personal communication, City of Seattle, Seattle, WA, July.

Prettenthalter F E and Steininger K W (1999) From ownership to service use lifestyle: The potential of car sharing, Ecological Economics, 28, 443-453.

Reynolds E (2001) Telephone interview, Autoshare, Toronto, Ontario, 9 August.

Roberts B (2001) Telephone interview, Communauto, Montreal, Quebec, 10 August.

Röhrleef, M (2003) Interview, Project Assistant, Üstra, Hanover, Germany, 26 September.

Rosenzweig, N (2003) Interview, Vice President of Marketing, zipcar, Boston, 7 October

Saunders J, Rye T, Celikel N A, Saleh W (1999) Edinburgh City Car Club goes live. World Transport Policy and Practice, 5(3), 139-154.

Scheurer J (2001) Car Free and Car Reduced Housing Development, Murdoch University, Western Australia, 23 August. Visit http://wwwistp.murdoch.edu.au/publications/projects/carfree/carfree.html. Last accessed 4 August 2004.

Shaheen S, Sperling D and Wagner C (1998) Carsharing in Europe and North America: Past, present and future, Transportation Quarterly, 52(3), 35-52.

Shaheen S, Meyn M and Wipyewski K (2003) US shared-use vehicle survey findings: Opportunities and obstacles for car sharing and station car growth, Transportation Research Record, 1841, 90-98.

Shaheen S, Schwartz A, and Wipyewski K (2004) US car-sharing and station car policy considerations: Monitoring growth, trends and overall impacts, Transportation Research Record, 1887, 128-136

Slotnick, L (2003) Interview, Director of Operations, zipcar, Boston, MA, 8 October.

Steininger K, Vogl C and Zetti R (1996) Car sharing organisations: The size of the market segment and revealed change in mobility behaviour, Transport Policy, 3(4), 177-185. 
Stewart G (1999) Car Sharing, The Urban Environment and Development Committee, City of Toronto, Ontario. Visit

http://www.city.toronto.on.ca/legdocs/1999/agendas/council/cc/cc990511/ud7rpt/cl001.htm. Accessed 6 August 2005.

Theunissen R (2001) Interview, the Stichtingvoor Gedeeld Autogebruik, Utrecht, Netherlands, 11 December.

Theunissen R (2003) Interview, the Stichtingvoor Gedeeld Autogebruik, Utrecht, Netherlands, 16 September

Transit Cooperative Research Program (2005) Car sharing: How and where it succeeds, Project B-26, Transit Cooperative Research Program, Federal Transit Administration, Washington DC, July.

Traue, R (2003) Interview, Cambio, Bremen, Germany, 30 September.

Vuchic V R (1981) Urban public transportation: Systems and technology, Prentice-Hall Inc., Englewood Cliffs, NJ.

White K (2001) Telephone interview, City Car Share, San Francisco, CA, 7 August.

\section{Acknowledgements}

The paper draws on results from two studies. First, the European Commission DG Research 5th Framework Programme City of Tomorrow-sponsored MOSES (Mobility Services for Urban Sustainability) project. The review was completed as part of the work package on Integration into Urban Planning and was commissioned by the London Borough of Southwark, the London Borough of Sutton, and Sustainable Energy Action. Second, it draws on a series of interviews conducted as part of a study tour of European, US and Canadian car club operators in Autumn 2003. The author is grateful to the Winston Churchill Memorial Trust for supporting this research. 